\title{
Diagnostic Value of Transbronchial Needle Aspiration Cytology in Sarcoidosis
}

\author{
Sarkoidozda Transbronşiyal İnce İğne Aspirasyon Sitolojisinin \\ Tanısal Değeri
}

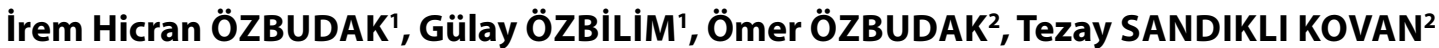

Departments of ${ }^{1}$ Pathology and ${ }^{2}$ Chest Diseases, Akdeniz University, Faculty of Medicine, ANTALYA, TURKEY

\begin{abstract}
Objective: Sarcoidosis is a systemic granulomatous inflammation that occurs as a result of disturbed immune regulation in individuals exposed to certain environmental agents. Although tissue sampling is considered the "gold standard" for the diagnosis of sarcoidosis, a medically treated disease, minimally invasive diagnostic methods are preferred instead of surgical tissue sampling. Transbronchial needle aspiration has been reported as an effective diagnostic method.
\end{abstract}

Material and Method: In this study, transbronchial needle aspiration cytology samples were assessed from 38 patients where sarcoidosis was suspected clinically and radiologically. The existence of epithelioid histiocytes and/or giant cells that formed granulomas was used as a cytological diagnostic criterion for chronic granulomatous inflammation. The presence of lymphocytes and/or germinal center cells, and of histiocytes in lymph nodes was regarded as adequate sampling criteria.

Results: A total of 31 out of the 38 patients were diagnosed as sarcoidosis with clinical, radiological and microbiological findings, after chronic granulomatous inflammation was considered by cytologic assessment. Cytologic diagnosis was achieved in: 4 of 7 patients with sampling from a single lymph node region, 25 of 28 patients with sampling from two different lymph node regions and 2 of 3 patients with sampling from three different lymph node regions. Two of the 7 patients who could not be diagnosed cytologically underwent a transbronchial parenchyma biopsy and the rest were diagnosed histologically from mediastinoscopic lymph node sampling.

Conclusion: We would like to emphasize that transbronchial needle aspiration is a successful diagnostic method. We highlighted the adequacy criteria of cytological sampling and the encountered cytological findings of chronic granulomatous inflammation.

Key Words: Sarcoidosis, Lymphadenopathy, Aspiration biopsy, Fine-needle

\section{ÖZ}

Amaç: Sistemik bir granülomatöz inflamasyon olan sarkoidozisin bilinen çevresel ajanlara maruziyet ile ortaya çıkan immün regülasyon bozukluğunun bir sonucu olduğu düşünülmektedir. Sarkoidozis medikal olarak tedavi edilebildiğinden, doku örneklemesi tanıda "Altın Standart" olarak kabul edilmekle birlikte, cerrahi doku örneklemesi yerine minimal invaziv tanı yöntemleri tercih edilmektedir. Transbronşiyal ince iğne aspirasyon sitolojisinin etkili bir tanı yöntemi olabileceği bildirilmektedir.

Gereç ve Yöntem: Bu çalışmada, klinik ve radyolojik olarak sarkoidozis şüphesi olan 38 olgudan alınan transbronşiyal ince iğne aspirasyon sitolojisi değerlendirilmiştir. Kronik granülomatöz yangı sitolojik tanı kriteri olarak granülom yapılanması gösteren epiteloid histiositlerin ve/veya dev hücrelerin varlığı kullanılmıştır. Transbronşiyal ince iğne aspirasyonundan hazırlanan preparatlarda lenf dügümü yapısına ait lenfositlerin ve/veya germinal merkeze ait hücresel elemanların, histiositlerin görülmesi yeterli örnekleme kriteri olarak kabul edilmiştir.

Bulgular: 31 olguda transbronşiyal ince iğne aspirasyonundan kronik granülomatözyangı tanısıverilmişveklinik, radyolojik, mikrobiyolojik bulgularla olgular 'Sarkoidozis' olarak kabul edilmiştir. Tek lenf düğümü örneklenen 7 olgunun 4'ünde, iki lenf dügümü örneklenen 28 olgunun 25 'inde ve üç lenf düğümü örneklenen 3 olgunun 2'sinde tanıya ulaşılmıştır. Sitolojik olarak tanı verilemeyen 7 olgudan 2'sine transbronşial parankimal doku biyopsisi, 5'ine mediastinoskopik lenf düğümü örneklemesi yapılmış ve histopatolojik olarak kronik granülomatöz yangı tanısına ulaşılmıştır.

Sonuç: Çalışmamızda, sarkoidozis olgularında transbronşiyal ince iğne aspirasyon sitolojisinin başarılı bir tanı yöntemi olarak kabul edilebileceği, sitolojik olarak örneğin yeterlilik kriterleri ve granülomatöz yangının sitomorfolojik özellikleri vurgulanmıştır.

Anahtar Sözcükler: Sarkoidozis, Lenfadenopati, Aspirasyon biyopsisi, İnce iğne 


\section{INTRODUCTION}

Sarcoidosis is a chronic, multisystemic, granulomatous disease of unknown etiology and usually presents with pulmonary and lymphatic system involvement (1). It is characterized by non-caseating granulomas and multinuclear giant cells that usually accompany these lesions. It is thought to develop as a result of an immune regulation disorder following exposure to known environmental agents in genetically predisposed persons. The first clinical presentation of sarcoidosis depends on the organ involved. The diagnosis is made by the presence of a cytological or histological appearance of non-caseating granulomas in addition to the clinical and radiological findings and ruling out of other causes of granulomatous inflammation (2).

Sarcoidosis can be seen globally but its incidence varies between countries and ethnic groups. Its incidence is $40 / 100000$ in Europe while it is rare in northeast Asia. It is more frequent in females and is usually seen before the age of 40 with a peak between 20 and 29 (3).

The diagnosis of sarcoidosis requires the presence of granulomas in two or more organs and the lack of known agent or process that would cause a granulomatous reaction (4).

Microscopically, sarcoid granulomas are non-necrotic densely organized collections of epithelioid histiocytes. They generally contain giant cells and are surrounded by peripheral mantle leukocytes. They may contain nonspecific inclusions such as Schaumann's, asteroid and Hamazaki-Wesenberg bodies and birefringent crystals (5).

The need for cytological/pathological diagnosis is currently debated as more than $70 \%$ of sarcoidosis cases show spontaneous resolution. Sarcoidosis can be treated medically and minimal invasive diagnostic methods are therefore preferred although tissue sampling is the "Golden Standard" for diagnosis. Transbronchial fine needle aspiration cytology (TBFNAC) is suggested as an effective diagnostic method (6).

The aim of this study was to evaluate the efficacy of mediastinal/hilar lymph node sampling by TBFNAC without tissue biopsy for sarcoidosis diagnosis.

\section{MATERIAL and METHOD}

We evaluated a total of 38 cases with a clinical or radiological suspicion of sarcoidosis in this study. The cases underwent fiberoptic bronchoscopy at the Akdeniz University Facuty of Medicine Pulmonary Disease Department and TBFNAC samples were obtained from the mediastinal and/or hilar lymph nodes using a 21-gauge Wang needle. Most of the material obtained from the patient was used for preparing direct smears besides the patient and these were sent to the Pathology Department after alcohol fixation. Some material was sent to microbiology for cultures. Smear preparations from the TBFNAC samples were stained with hematoxylin-eosin and evaluated with a dual head microscope by two pathologists. The cytological criteria for chronic granulomatous inflammation was the presence of epithelioid histiocytes and/or giant cells with granulomatous organization (Figure 1A-H) (7). The presence of lymphocytes from the lymph node structure and/or cellular elements of germinal centers and sinus histiocytes was used as the criterion for adequate sampling.

\section{RESULTS}

There were $24(63.2 \%)$ females and $14(36.8 \%)$ males. The mean age was 48.4 (27-74). The mean number of preparations from each case was 9 (6-15). 31 of the 38 cases $(81.6 \%)$ received a diagnosis of non-necrotizing chronic granulomatous inflammation with the TBFNAC samples. The cases were accepted as "Sarcoidosis" if the microbiology material cultures sent at the same time were reported as negative and the clinical and radiological findings were consistent with the diagnosis. The lymph node sample was obtained from paratracheal in 35 , subcarinal in 30 , hilar in 6 and precarinal in 1 case (Table I). The diagnosis of chronic granulomatous inflammation was made in 4 of 7 cases where a single lymph node, 25 of 28 cases where two lymph nodes and 2 of 3 cases where three lymph nodes were sampled. The sampled lymph nodes were paratracheal in 6 , subcarinal in 3, hilar in 2 and precarinal in 1 of the 7 cases where a cytological diagnosis could not be provided. Two cases underwent transbronchial parenchymal tissue biopsy and 5 cases mediastinoscopic lymph node sampling when the TBFNAC results were negative and a histopathological diagnosis of non-necrotizing chronic granulomatous inflammation was made.

\section{DISCUSSION}

The TBFNA procedure can be easily performed in sarcoidosis cases with pulmonary and lymph node involvement, increasing the role of cytology in the diagnosis. Tambouret et al. have reported that the FNAC method is a good diagnostic method for sarcoidosis diagnosis when evaluated together with the clinical, radiological and laboratory data (8). The procedure is simple, safe and inexpensive and can easily be performed on a same-day basis. The result is also obtained quicker than with conventional histopathological evaluation. 

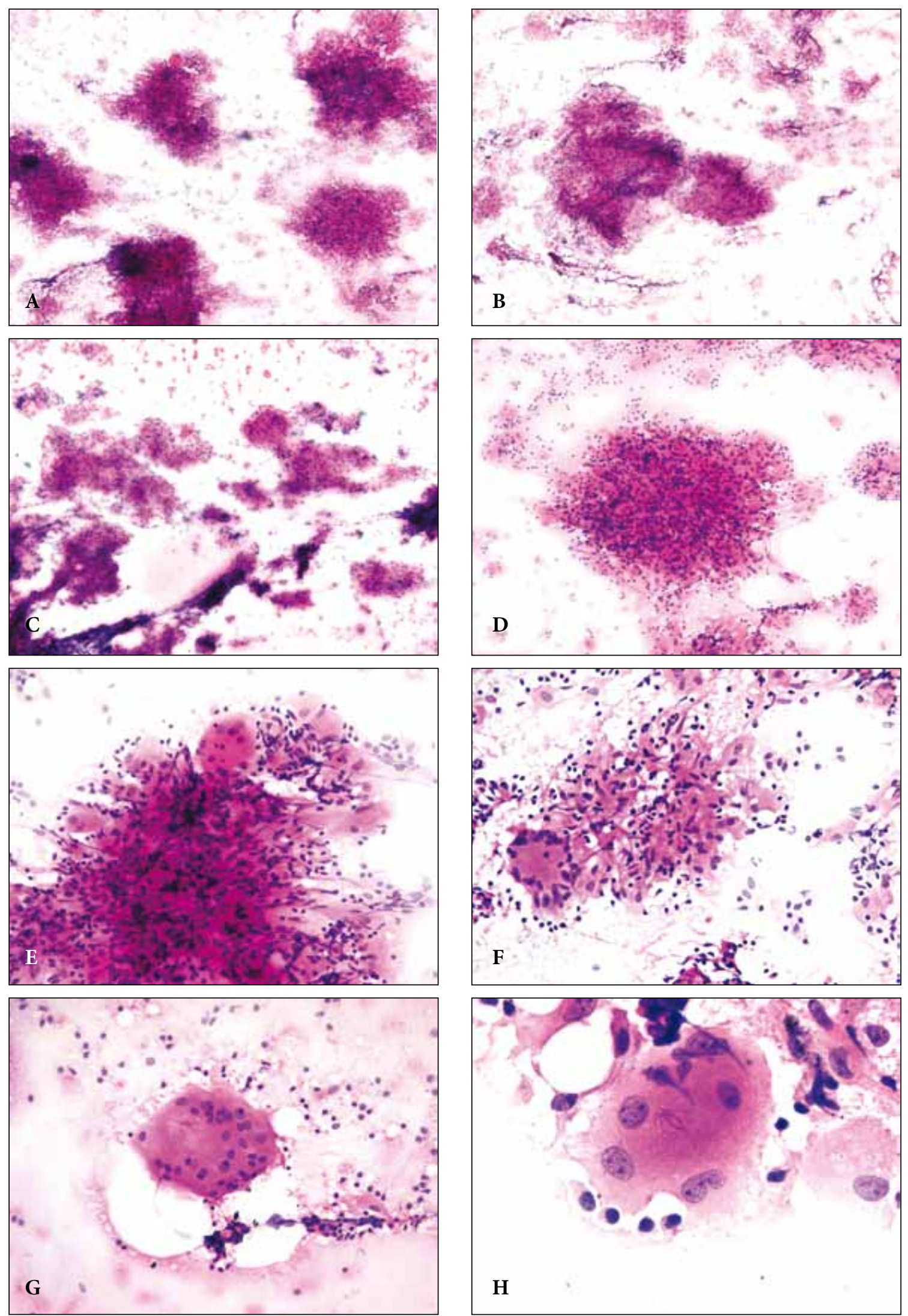

Figure 1: Transbronchial fine needle aspiration cytology - Sarcoidosis; Granulomas consisting of epithelioid histiocytes, giant cells and lymphocytes, (H\&E x50) (A-C); (x100) (D); (x200) (E,F). Giant cell formation containing asteroid body, (H\&E x200) (G); (x630) (H). 
Table I: The distribution of lymph nodes in the cases and the results of TBNA

\begin{tabular}{|l|c|c|c|c|}
\hline Lymph nodes & Paratracheal, $\mathbf{n}(\%)$ & Subcarinal, $\mathbf{n}(\%)$ & Hilar, $\mathbf{n}(\%)$ & Precarinal, $\mathbf{n}(\%)$ \\
\hline Diagnostic & $29(76.3 \%)$ & $21(55.3 \%)$ & $4(8.9 \%)$ & $0(0 \%)$ \\
\hline Non-diagnostic & $6(15.8 \%)$ & $9(23.7 \%)$ & $2(4.4 \%)$ & $1(2.6 \%)$ \\
\hline Not sampled & $3(7.9 \%)$ & $8(21.1 \%)$ & $32(71.1 \%)$ & $37(97.4 \%)$ \\
\hline Total & \multicolumn{4}{|c|}{$38(100)$} \\
\hline
\end{tabular}

The accuracy of the TBFNAC method in mediastinal/hilar sarcoidosis cases depends on the thickness of the needle, the ability of the bronchoscopist and the number of sampled lymph nodes. Obtaining samples from multiple lymph nodes is suggested for an accurate diagnosis. Hilar lymph nodes are involved most often but paratracheal lymph node enlargement is also frequently seen. No difference has been found between the paratracheal and hilar lymph nodes regarding adequacy of the TBFNA method (9). A $90 \%$ success rate for sarcoidosis diagnosis has been reported for an 18-gauge needle as it is also possible to obtain a tissue biopsy in addition to cytological material depending on the length of the needle (10). Only cytological material can be obtained when a 22-gauge needle is used (9) so there are reports that it can frequently be inadequate in making a diagnosis of granulomatous inflammation when the sampling is also not carried out properly. We used a 21-gauge needle and were able to make a diagnosis of chronic granulomatous inflammation in 31 out of 38 cases. The cases where a diagnosis could not be provided underwent mediastinoscopy / transbronchial parenchymal tissue biopsy and these tissue biopsies were reported as consistent with non-necrotizing chronic granulomatous inflammation.

The first step in evaluating the FNAB sample should be determining the adequacy of the sample. When there are no cytopathological findings of granulomatous reaction, the adequacy of the sample is determined according to the presence/amount of cellular elements of lymphoid tissue. However, there are widely differing opinions on what this amount should be. A previous study by Baker et al. has reported a negative predictive value of $78 \%$ for samples containing lymphocytes, decreasing to $36 \%$ for samples without lymphocytes (11). Alsharif et al. have reported that the presence of a least 40 benign lymphocytes in a highpowered field in areas with the most cellularity on a smear preparation can be used as an adequacy criterion (12). The same investigators have accepted samples as adequate when large groups of lymphocytes or pigmented macrophages were present or numerous macrophages loaded with anthracotic pigment could be seen. Our laboratory accepts the presence of dense lymphocytes in at least one area of smear preparation with a semiquantitative evaluation as a criterion for adequacy. We retrospectively evaluated our cases for this study and saw that the adequacy criteria specified in the Alsharif et al. study were met and concluded that using such a threshold value increased the reliability and reproducibility of the study (12).

Granulomas are defined as a variable-sized loose collection of non-pigmented epithelioid or spindle-like histiocytes (7). They are generally accompanied by lymphocytes and more rarely by necrotic material. The epithelioid histiocytes that make up the granulomas are kidney-shaped, spindle-like cells with a folded or boomerang shaped nucleus, faintly stained cytoplasm and non-prominent cell borders. There may be multinuclear giant cells but these are generally rare. Necrosis is usually not seen on the background of the smear in sarcoidosis cases (13). The granulomas described in this study also possess the described cytomorphological features.

The sarcoidosis diagnosis is usually made by demonstrating non-caseating granulomas on biopsy and excluding other granuloma causes in practice. The patients usually undergo transbronchial parenchymal tissue biopsy and one study has shown these biopsies to have a diagnostic adequacy of $70 \%$ with sensitivity increasing with higher number of samples (14). Many studies have shown that the conventional TBFNAC method has similar adequacy rates, and there are reports of high sensitivity rates such as $90 \%$ (15-19). The biggest advantage of TBFNAC method when compared with transbronchial parenchymal tissue biopsy method is that the morbidity rate is low and potential complications such as pneumothorax and bleeding are encountered less often.

The differential diagnosis of sarcoidosis includes infectious causes, mycobacterial and fungal infections in the first place. The patient's clinical, radiological and laboratory findings provide a guideline but it is suggested that part of the sample be sent for culture and special histochemical stains for patients coming from a region with a high incidence of mycobacterial infections or where fungal 
infections are encountered and also in immunosuppressed patients or those receiving chemotherapy (13). Another condition that must be kept in mind in the differential diagnosis of sarcoidosis is the possible presence of sarcoidlike granulomas in malignancies (especially non-small cell lung carcinomas, and lymphoid and germ cell tumors) (20-22). It is thought that sarcoid-like granulomas seen in the lymph node represent a local $\mathrm{T}$ cell-mediated immune reaction against possible antigens or other factors released from the tumor tissue (23). Sarcoidosis granulomas also contain B cells as a difference at the histopathological level (24).

In conclusion, this study's data and those already present in the literature indicate that TBFNAC is a successful diagnostic method for sarcoidosis. Defining a granuloma structure cytologically and determining the threshold lymphocyte count value in samples from the mediastinal/hilar lymph node increases the reliability and reproducibility of the method and also ensures standardization of cytological evaluation.

\section{REFERENCES}

1. Statement on sarcoidosis. Joint Statement of the American Thoracic Society (ATS), the European Respiratory Society (ERS) and the World Association of Sarcoidosis and Other Granulomatous Disorders (WASOG) adopted by the ATS Board of Directors and by the ERS Executive Committee, February 1999. Am J Respir Crit Care Med 1999, 160:736-755

2. Hunninghake GW, Costabel U, Ando M, Baughman R, Cordier $J F, d u$ Bois R, Eklund A, Kitaichi M, Lynch J, Rizzato G, Rose C, Selroos O, Semenzato G, Sharma OP: ATS/ERS/WASOG statement on sarcoidosis. American Thoracic Society/European Respiratory Society/World Association of Sarcoidosis and other Granulomatous Disorders. Sarcoidosis Vasc Diffuse Lung Dis 1999, 16:149-173

3. Marchall R, Thiers B, Judson MA: Sarcoidosis. In Wolff K, Goldsmith LA, Katz SI. (Eds): Fitzpatrick's Dermatology in General Medicine. New York, NY, McGraw Hill Medical, 2008, 1484-1493

4. Barnett BP, Sheth S, Ali SZ: Cytopathologic analysis of paratracheal masses: a study of 737 cases with clinicoradiologic correlation. Acta Cytol 2009, 53:672-678

5. Jorns JM, Knoepp SM: Asteroid bodies in lymph node cytology: infrequently seen and still mysterious. Diagn Cytopathol 2011, 39:35-36

6. Trisolini R, Tinelli C, Cancellieri A, Paioli D, Alifano M, Boaron M, Patelli M: Transbronchial needle aspiration in sarcoidosis: yield and predictors of a positive aspirate. J Thorac Cardiovasc Surg 2008, 135:837-842

7. Mukhopadhyay S, Gal AA: Granulomatous lung disease: an approach to the differential diagnosis. Arch Pathol Lab Med 2010, 134:667-690

8. Tambouret $R$, Geisinger KR, Powers CN, Khurana KK, Silverman JF, Bardales R, Pitman MB: The clinical application and cost analysis of fine-needle aspiration biopsy in the diagnosis of mass lesions in sarcoidosis. Chest 2000, 117:1004-1011
9. Chapman JT, Mehta AC: Bronchoscopy in sarcoidosis: diagnostic and therapeutic interventions. Curr Opin Pulm Med 2003, 9: 402-407

10. Wang KP, Terry P, Marsh B: Bronchoscopic needle aspiration biopsy of paratracheal tumors. Am Rev Respir Dis 1978, 118: 17-21

11. Baker JJ, Solanki PH, Schenk DA, Van Pelt C, Ramzy I: Transbronchial fine needle aspiration of the mediastinum. Importance of lymphocytes as an indicator of specimen adequacy. Acta Cytol 1990, 34:517-523

12. Alsharif M, Andrade RS, Groth SS, Stelow EB, Pambuccian $S E$ : Endobronchial ultrasound-guided transbronchial fineneedle aspiration: the University of Minnesota experience, with emphasis on usefulness, adequacy assessment, and diagnostic difficulties. Am J Clin Pathol 2008, 130:434-443

13. Cameron SE, Andrade RS, Pambuccian SE: Endobronchial ultrasound-guided transbronchial needle aspiration cytology: a state of the art review. Cytopathology 2010, 21:6-26

14. Gilman MJ, Wang KP: Transbronchial lung biopsy in sarcoidosis. An approach to determine the optimal number of biopsies. Am Rev Respir Dis 1980, 122:721-724

15. Bordoni R: Consensus conference: multimodality management of early- and intermediate-stage non-small cell lung cancer. Oncologist 2008, 13:945-953

16. Rami-Porta R, Crowley JJ, Goldstraw P: The revised TNM staging system for lung cancer. Ann Thorac Cardiovasc Surg 2009, 15:4-9

17. Tournoy KG, Burgers SA, Annema JT, Vermassen F, Praet M, Smits M, Klomp HM, van Meerbeeck JP, Baas P: Transesophageal endoscopic ultrasound with fine needle aspiration in the preoperative staging of malignant pleural mesothelioma. Clin Cancer Res 2008, 14:6259-6263

18. Wallace WA, Monaghan HM, Salter DM, Gibbons MA, Skwarski $K M$ : Endobronchial ultrasound-guided fine-needle aspiration and liquid-based thin-layer cytology. J Clin Pathol 2007, 60: 388-391

19. Wang KP, Fuenning C, Johns CJ, Terry PB: Flexible transbronchial needle aspiration for the diagnosis of sarcoidosis. Ann Otol Rhinol Laryngol 1989, 98:298-300

20. Kennedy MP, Jimenez CA, Mhatre AD, Morice RC, Eapen GA: Clinical implications of granulomatous inflammation detected by endobronchial ultrasound transbronchial needle aspiration in patients with suspected cancer recurrence in the mediastinum. J Cardiothorac Surg 2008, 3:3-8

21. Steinfort DP, Irving LB: Sarcoidal reactions in regional lymph nodes of patients with non-small cell lung cancer: incidence and implications for minimally invasive staging with endobronchial ultrasound. Lung Cancer 2009, 66:305-308

22. Brincker H: Sarcoidosis and malignancy. Chest 1995, 108: 1472-1474

23. Kurata A, Terado Y, Schulz A, Fujioka Y, Franke FE: Inflammatory cells in the formation of tumor-related sarcoid reactions. Hum Pathol 2005, 36:546-554

24. Brincker H, Pedersen NT: Immunohistologic separation of B-cell-positive granulomas from B-cell-negative granulomas in paraffin-embedded tissues with special reference to tumorrelated sarcoid reactions. APMIS 1991, 99:282-290 